\title{
Concluding Remarks: The Tropical Legumes Projects Empowered Communities in a Wide Variety of Assets
}

After 12 years of activity, the Tropical Legumes (TL) projects come to an end the year 2019. In addition to quantitative impact assessment, this publication brings to light various stakeholders' own words about the kind of benefits they have made thanks to the TL projects. Research institutions, management and technical staff, extension services, NGOs, public and private seed companies, agro-dealers, farmer cooperatives, farmer groups, individual seed entrepreneurs, farmers, women farmers, processors, farm implement makers, middlemen, and traders have all shared their unique impact stories for being part of TL families.

From poor knowledge of recently developed legume technologies, most communities in the project areas of the target countries have been widely exposed and have a very good knowledge and use of newly released varieties of groundnut, common bean, cowpea and chickpea. This allowed them to increase crop productivity and production, improve resilience to advert weather conditions, and enhance family welfare through various livelihood assets such as ownership of land, houses, transport means, market connections, social recognition, food security, children education, health care, etc. The huge smiles on different faces pictured in this publication is illustrative.

Women conditions have tremendously improved as TL interventions specifically targeted women empowerment through capacity building and involvement in seed business. Many of the under-served women that the TL projects supported have had their living standards and those of their respective families in the target Eastern and West Africa countries lifted higher.

Community food security and resilience building is not a one initiative task. We strongly believe that future research and/or development interventions will leverage on the current dynamics set out and nurtured throughout the 12 years of TL projects. We are proud to deliver on this as a team made of diverse national and international partners. 
Open Access This chapter is licensed under the terms of the Creative Commons Attribution 4.0 International License (http://creativecommons.org/licenses/by/4.0/), which permits use, sharing, adaptation, distribution and reproduction in any medium or format, as long as you give appropriate credit to the original author(s) and the source, provide a link to the Creative Commons licence and indicate if changes were made.

The images or other third party material in this chapter are included in the chapter's Creative Commons licence, unless indicated otherwise in a credit line to the material. If material is not included in the chapter's Creative Commons licence and your intended use is not permitted by statutory regulation or exceeds the permitted use, you will need to obtain permission directly from the copyright holder.

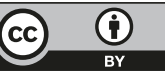

